\title{
A Study to Assess the Effectiveness of Memory-enhancement Technique (MET) on Memory Retention among Second Year BSc Nursing Students in Kasturba Gandhi Nursing College at Puducherry
}

\author{
Subramaniyan Prabhavathy ${ }^{1}$, Renuka $\mathrm{K}^{2}$
}

\begin{abstract}
Background: Memory is the faculty of the brain by which the data information is encoded, stored, and retrieved when needed. Although investigations into human memory have been occurring for over 100 years, the basic factors of memory are still not understood. Factors, such as attention, acquisition, encoding of material, rehearsal, experience, and retrieval, are important determinants of memory ability. Without memory, there can be no learning, but many students have never learned nor have been taught any methods for increasing their memory abilities. Therefore, the purpose of this study was to test the effectiveness of memory-enhancement techniques (METs) teaching on nursing students. Aims and objectives: To assess the memory retention among BSc Nursing second year students in a selected college at Puducherry, to evaluate the effectiveness of the memory-enhancement therapy in memory retention among BSc Nursing second year students at the college in Puducherry, and to associate the level of memory retention among BSc Nursing second year students with the selected demographic variables. Materials and methods: A preexperimental research design was adopted for the study. A sample of 95 students from second year BSc Nursing was selected by using a convenient sampling technique. The pretest level of memory retention was assessed by using a multifactorial memory questionnaire. After the implementation of METs, the posttest level of memory retention was again assessed by using a multifactorial memory questionnaire.

Major findings: In pretest, out of 95 samples, the MMQ level, 4 (4.2\%) had a below average, $69(72.6 \%)$ had average, $14(14.7)$ had above average, $5(5.3 \%)$ had high, and $3(3.2 \%)$ had very high MMQ level and in the posttest, $2(2.1 \%)$ had below average, 54 (56.8\%) had average, $18(18.9 \%)$ had above average, $14(14.7 \%)$ had high, and $7(7.4 \%)$ had very high MMQ level. There was a significant difference between pretest and posttest levels of memory retention.

Conclusion: The study proves that METs are highly effective for students for recalling and improving the memory retention. The subjects in the research group expressed more satisfaction on using METs.

Keywords: BSc Nursing students, Improving the memory retention, Memory-enhancement techniques.

Pondicherry Journal of Nursing (2021): 10.5005/jp-journals-10084-13118
\end{abstract}

\section{INTRODUCTION}

In daily life, we take in new information and store it in our brain, maintaining it and recalling it is depending on our needs. This happens because our brain has the capability of learning new skills and experiences, storing what has been learned, and reusing the stored knowledge. These capabilities of storing and reusing experiences and skills are informally known as the human memory system. ${ }^{1-5}$ Generally, there are two different memory types, shortterm and long-term memory, that store and access information differently, and many brain regions are involved in the process. Students are persons formally engaged in learning, especially enrolled in gaining knowledge, developing professional skills, and achieving their study goals, ${ }^{6-10}$ whereas some students are identified as having special needs in studies having the problems of slow learning, forgetfulness, lack of attention, and concentration when they are at the infancy stage. But the majority of students are not identified until they enter into the college system. Most of the adolescents differ from one another physically, intellectually, emotionally, and culturally. Slow learners are those adolescents who are low in achieving academic skills and often ignored by others as dull, lazy in the part of the college setting as they not only lag behind
${ }^{1}$ Department of Mental Health Nursing, Kasturba Gandhi Nursing College, Sri Balaji Vidyapeeth (Deemed to be University), Puducherry, India

${ }^{2}$ Department of Medical Surgical Nursing, Kasturba Gandhi Nursing College, Sri Balaji Vidyapeeth (Deemed to be University), Puducherry, India

Corresponding Author: Subramaniyan Prabhavathy, Department of Mental Health Nursing, Kasturba Gandhi Nursing College, Sri Balaji Vidyapeeth (Deemed to be University), Puducherry, India, Phone: +91 9486537848, e-mail: prabavathy111@gmail.com

How to cite this article: Prabhavathy S, Renuka K. A Study to Assess the Effectiveness of Memory-enhancement Technique (MET) on Memory Retention among Second Year BSc Nursing Students in Kasturba Gandhi Nursing College at Puducherry. Pon J Nurs 2021;14(3):59-61.

Source of support: Nil

Conflict of interest: None

other students in academics but also in areas of social, emotional, and psychological wellbeing and leading to memory problems. ${ }^{11-15}$ According to the study of Paula E. Hartman-Stein and Asenath La Rue,

(C) The Author(s). 2021 Open Access This article is distributed under the terms of the Creative Commons Attribution 4.0 International License (https://creativecommons [2]. org/licenses/by-nc/4.0/), which permits unrestricted use, distribution, and non-commercial reproduction in any medium, provided you give appropriate credit to the original author(s) and the source, provide a link to the Creative Commons license, and indicate if changes were made. The Creative Commons Public Domain Dedication waiver (http://creativecommons.org/publicdomain/zero/1.0/[3]) applies to the data made available in this article, unless otherwise stated. 
it has been estimated that about $5-15 \%$ of college-going adults suffer from difficulty in retention of information, backwardness, and forgetfulness. Nursing and Nursing education have come a long way over the past few decades and have undergone several changes in learning and development in technology. In these competitive times, it is essential to transform nursing students from slow learners and textbook muggers and encouraging them in improving attention, concentration in studies, remembrance, and critical thinking. ${ }^{16-22}$

The learning and memory-enhancing strategies to support the voluminous amount of course material, which needs to be completed in the 4 years of duration, is minimal. Hence, many of the students are needed to change their learning and memoryenhancing strategies to keep in remembering the content, encouraging the interest of the students and empower them for future self-learning and remembering, and realizing this need, the newer techniques that keep up with the growing times are necessary for nursing education as well, one such method is the "METs." This is a multidimensional technique, which consists of mnemonic forms often used by the students to aid in recalling the information gained, it is a simple way to remember, where the students might associate a term they need to remember with the idea by utilizing various techniques. The main purpose of it is that the students should study the techniques and incorporate them for easy learning, improve storage, and retention of memory, during their exams for better results. These techniques include the loci and mind mapping technique, visualization method, attention and concentration, minor peg system, major peg system, etc. ${ }^{23-28}$

\section{Statement Problem}

A Study to Assess the Effectiveness of MET on Memory Retention among Second year BSc Nursing Students in Kasturba Gandhi Nursing College at Puducherry.

\section{Aims and Овjectives}

- To assess the memory retention among BSc Nursing second year students in a selected college at Puducherry.

- To evaluate the effectiveness of METs in memory retention among BSc Nursing second year students at the college in Puducherry.

- To associate the level of memory retention among BSc Nursing second year students with the selected demographic variables.

\section{Hypothesis}

$\mathrm{H}_{1}$ : There is a significant difference in the memory retention before and after implementing the MET.

$\mathrm{H}_{2}$ : There is a significant association between the effects of METs on memory retention with selected sociodemographic variables.

\section{Materials and Methods}

A preexperimental research design (one-group pretest and posttest design) was adopted for the study. The population of the study was BSc Nursing students. A sample of 95 students from second year BSC Nursing was selected by using a convenient sampling technique. A pretest level of memory retention was assessed by using a multifactorial memory questionnaire. After the implementation of METs, the posttest level of memory retention was again assessed by using the multifactorial memory questionnaire. The data were analyzed by using descriptive and inferential statistics, such as frequency, percentage, mean, standard deviation, and paired t-test.

\section{Major Findings}

Fig. 1 shows in the pretest, $4.2 \%$ of students' memory retention was below average, $72.6 \%$ were average, $14.7 \%$ were above average, $5.3 \%$ were high, and $3.2 \%$ were very high and in posttest, $2.1 \%$ of students' memory retention were below average, $56.8 \%$ were average, $18.9 \%$ were above average, $14.7 \%$ were high, and $7.4 \%$ were very high. Table 1 shows the mean score of the level of memory retention in nursing students was 50.746 with a standard deviation of 11.493, whereas after the implementation of the MET, the posttest memory mean score was increased about 58.758 with a standard deviation of 12.993. The improvement of the memory level was statistically tested by the paired $t$-test, which was found to be highly statistically significant at $p<0.0001$ level. This indicates that the MET was effective in improving memory among BSC Nursing second year students. Therefore, hypothesis $\mathrm{H}_{1}$ was accepted.

Table 2 shows that there was a significant ${ }^{*}(\mathrm{~S})$ association between the pretest level of memory retention with the demographic variables, such as BMI, father education, father occupation, mother education, wake up time, duration of study time, electronic gadgets, stress and anxiety, and duration of sleep. The association between the memory retention with selected demographic variables was significantly associated with memory retention because it was statistically significant at $p<0.0001$. Hence, the stated hypothesis $\mathrm{H}_{2}$ was also accepted.

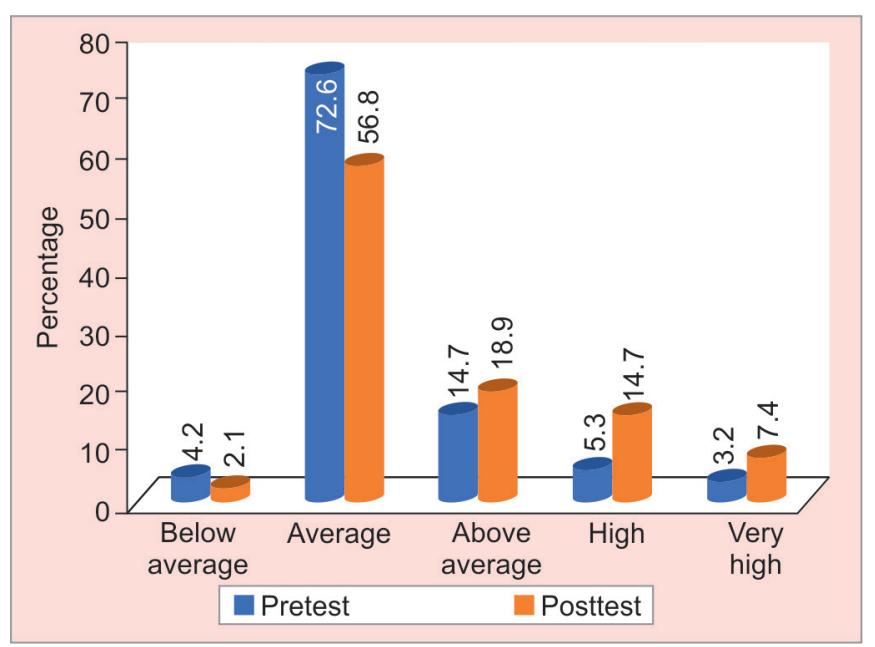

Fig. 1: Effectiveness of METs

Table 1: Comparison of the mean pretest and posttest scores regarding the memory retention

\begin{tabular}{llcc}
\hline S.No & Level of memory retention & Mean & Std. deviation \\
\hline 1 & Pretest & 50.746 & 11.493 \\
2 & Posttest & 58.758 & 12.993 \\
\hline
\end{tabular}


Table 2: Association between pretest level of memory retention with selected demographic variables

\begin{tabular}{lcc}
\hline & KW/MW test/ & \\
Demographic variables & Mann-Whitney test & p value \\
\hline BMI & 4.1289 & $0.0008 \mathrm{~S}^{*}$ \\
Father's education & 11.3705 & $0.0227 \mathrm{~S}^{*}$ \\
Father's occupation & 11.7544 & $0.0083 \mathrm{~S}^{*}$ \\
Mother's education & 3.8477 & $0.0784 \mathrm{~S}^{*}$ \\
Wake-up time & 4.6653 & $0.0471 \mathrm{~S}^{*}$ \\
Duration of study time & 7.3005 & $0.7206 \mathrm{~S}^{*}$ \\
Electronic gadgets & 1.956 & $0.0256 \mathrm{~S}^{*}$ \\
Stress and anxiety & 1.1277 & $0.0387 \mathrm{~S}^{*}$ \\
Duration of sleep & 9.67 & $0.0004 \mathrm{~S}^{*}$ \\
\hline
\end{tabular}

\section{Conclusion}

The study proves that METs are highly effective for students for recalling and improving the memory retention. The subjects in the research group expressed more satisfaction on using METs.

\section{References}

1. Student Counseling Service. Long and Short Term Memory. The University of Chicago.web:Feb.2016

2. HafeezUllah Amin and Aamir Malik. EEG/ERP Analysis: Methods and Application. Memory Retention and Recall Process.1st edition: CRC; 2014:219-237. DOI:10.1201/b17605-11.

3. May CP, Einstein GO. Memory, a five day unit lesson plan for high school psychology teachers. American Psychological Association.

4. Basavanthappa BT, Textbook of research and statistics. Jaypee Brothers. 2002.

5. Forskyke Dr. Theoretical Consideration of Tsou Plot, Journal of Theoretical biology June 1991;150(4).

6. McDermottKB, RoedigerHL3rd.Effects of imagery on perceptual implicit memory tests.J ExpPsychol Learn MemCogn 1994 Nov;20(6):1379-1390. DOI: 10.1037//0278-7393.20.6.1379. PMID: 7983469.

7. Brennan WK. Shaping the education of slow learners. Routledge Publication 2018;36-49.

8. Suresh K Sharma. Textbook of nursing research and statistics; 3rd Edition. New Delhi. Reed Elsevier Publication: 2015.

9. Mozer MC, Lindsey RV. Predicting and improving memory rentention. Colorado: Elsevier Publication; 2016, p. 303-45.

10. Oermann MH, Gaberson KB. Evaluation and testing in nursing education. Springer Publishing Company; 2016, p. 222-230.
11. Alt. AL Memory enhancement in adult learners (Doctoral Dissertation, Montana State University-Bozeman, College of Education, Health \& Human Development), 2014, p. 1- 273.

12. Hertzog C, Kramer AF, Wilson RS, Lindenberger U. Enrichment effects on adult cognitive development. Psychol Sci 2018;9(1):1-65. DOI: $10.1111 /$ j.1539-6053.2009.01034.x.

13. Morrison $A B$, Chein JM. The promise and challenges of enhancing cognition by training working memory. Psychon Bull Rev 2011 Feb;18(1):46-60. DOI: 10.3758/s13423-010-0034-0. PMID: 21327348.

14. Cherry K. Attitude and memory in psychology. J Amer Psychol Assoc; 2018:78-84.

15. Forrin ND, Macleod CM, Ozubko JD. Widening the boundaries of the production effect. MemCognit 2012 Oct;40(7):1046-55. DOI: 10.3758/ s13421-012-0210-8. PMID: 22528825.

16. Hartman-Stein PE. Enhancing cognitive fitness in adult. New York: Springer; 2015. p. 107-124.

17. Hohalus L. Remembering to age successfully. Int Psychogeriatr 2018;19(1):137. DOI: 10.1017/S1041610206003760.

18. George W. Gividen Published By U.S. Department of Health, Education and Welfare National Institution of Education. 2017:67.

19. Sanatullova-Allison E. Memory retention in second language acquisition and instruction. IAFOR J Lang Learn 2014;1(1):N1. ISSN: 2188-9554.

20. Mohs RC, Ashman TA, Jantzen K. A study of the efficacy of a comprehensive memory enhancement program in healthy elderly persons. 2017;77(3):183-95. DOI: 10.1016/s0165-1781(98)00003-1.

21. Elizabeth $\mathrm{O}$. The effect of time span on memory retention among secondary school students. ObafemiAwolowo University. Nigeria; 2015. p. 1-74.

22. Irman I. The effectiveness of memory enhancement techniques in counseling of enhancing memory of students. Jurnal Ta'dib. 2018;2:1-10. Availabe from: http://ecampus.iainbatusangkar.ac.id/ ojs/index.php/takdib/index

23. Ullman MT, Lovelett JT. The role of memory enhancement techniques. Second Language Research 2018;34(1):39-65. DOI: $10.1177 / 0267658316675195$.

24. Van Geothem N. Hand book of neuroscience. Elsevier Publication 2018. p. 23-38.

25. Gehanabel A. The effectiveness of mind mapping as active learning strategy among nursing students. New York: Elsevier Publication 2015. p. 93-99.

26. De Lima NK, Jaeger A. Effect of prequestions versus postquestions on memory retention in children. Journal of Applied Research in memory and cognition 2016;9(4):555-63. Available from: http://doi. org/10.1016/j.jarmac.2020.08.005

27. Von Bertalanffy L. General system theory. British J Philosop Cognit Sci 1950;1(1):11-7. Available from: https://philpapers.org/ go.pl?id=VONAOO-2\&proxyld=\&u=https $\% 3 A \% 2 F \% 2 F d x . d o i$. org\%2F10.1093\%2Fbjps\%2FI.2.134

28. Pillado IA. Students experience with personalized learning: An examination using self-determination theory. New Delhi. Elsevier Publication; 2017. p. 199-212. 